\title{
PENGARUH KEJELASAN SASARAN ANGGARAN, TRANSPARANSI DAN PENGENDALIAN AKUNTANSI DAN PENGENDALIAN AKUNTANSI TERHADAP KINERJA MANAJERIAL PADA PEMERINTAH PROVINSI SULAWESI UTARA
}

\author{
Posumah Linda Natalia ${ }^{1}$, Lintje Kalangi ${ }^{2}$, Jessy D.L. Warongan ${ }^{3}$ \\ 1,2,3 Jurusan Akuntansi, Fakultas Ekonomi dan Bisnis Universitas Sam Ratulangi, Jl. Kampus Bahu, Manado, \\ 95115, Indonesia \\ E-mail : posumahlinda@gmail.com
}

\begin{abstract}
The purpose of this study was to determine the effect of the clarity of budget targets, transparency and accounting control on managerial performance in the North Sulawesi provincial government both partially and simultaneously. This hypothesis was tested using the t test and F test. The population in this study were all employees who worked on SKPD on the research object, sample in this research are managers, namely employees who occupy from the echelon two to the echelon for, with amount of responder counted 50 people. The analytical method used in this research is multiple regression analysis. The result of the analysis through the t test stated that the clarity of the budget target effects on the managerial performance of the provincial government of North Sulawesi. The transparency does not affect on the managerial performance of the province of North Sulawesi. The accounting control effects on the managerial performance of the province of North Sulawesi. The result of the analysis of the F test state that the clarity of budget targets, transparency and accounting control affect simultaneously on the managerial performance of the North Sulawesi province.
\end{abstract}

Keywords: Clarity of budget targets, Transparency, Accounting Control, Managerial performance

\section{PENDAHULUAN}

Pelaksanaan otonomi daerah memberikan warna berbeda pada sistem Pemerintahan Indonesia, yakni perubahan kewenangan dari pemerintah Pusat ke Pemerintah Daerah untuk menata dan menjalankan sendiri urusan pemerintahannya serta bertanggungjawab terhadap kepentingan masyarakat didaerah tersebut sesuai dengan peraturan perundang-undangan yang berlaku termasuk didalamnya mengenai pengelolaan keuangan daerah.

Berorientasi pada kepentingan masyarakat, organisasi sektor publik dalam hal ini pemerintah daerah diharapkan agar memiliki kinerja yang maksimal untuk senantiasa tanggap akan tuntutan lingkungannya, serta memberikan pelayanan yang transparan dan berkualitas sesuai tugas pokok dan fungsi masing-masing aparatur pemerintahan daerah. Semakin bersar tuntutan yang diterima aparutur pemerintahan daerah, maka semakin besar pula tanggung jawab yang harus diemban oleh penyelenggara pemerintahan daerah atas kepercayaan yang diamanatkan untuk mengatur dan menjalankan sistem pemerintahan.

Era globalisasi memberi peluang masyarakat untuk memonitor jalannya tata kelola pemerintahan di daerah masing - masing baik melalui media elektronik maupun media cetak. Dengan kata lain, kinerja pemerintah mulai dari tahap perencanaan sampai pertanggungjawaban semakin disorot oleh masyarakat. Oleh sebab itu pemerintah daerah harus lebih peka terhadap permintaan masyarakat guna memaksimalkan kinerjanya. Sebagian besar kinerja sektor publik dipengaruhi oleh kinerja aparat atau manajerial.

Kinerja manajerial merupakan kinerja para individu dalam kegiatan manajerial yang berimplikasi pada hasil yang dicapai oleh individu dalam tugas dan tanggungjawabnya terkait 
kegiatan manajerial. Kinerja manajerial dalam konteks pemerintahan dapat dijadikan cerminan dalam mencapai sasaran dan tujuan organisasi sebagai aplikasi dari visi dan misi organisasi atau instansi pemerintah. Selain dapat diukur, kinerja pemerintah juga dapat dinilai oleh masyaraat. Salah satu cara masyarakat dapat meniliai kinerja pemerintah yaitu lewat anggaran. Dalam sektor publik anggaran yang telah disusun dalam bentuk RAPBD harus diinformasikan kepada publik sehingga masyarakat selain mengetahui rencana anggaran yang dibuat pemerintah, masyarakat juga turut terlibat dalam memberi masukan.

Kejelasan sasaran anggaran merupakan bagian dari RPJMD dan RKPD. Dengan adanya sasaran anggaran yang jelas, pihak-pihak yang terlibat dalam penyusunan akan merasa terbantu, mereka akan dengan mudah menyusun target-target anggaran sehingga dalam perealisasianya, realisasi anggaran akan tepat sasaran dan terlaksana secara efektif dan efisien. Pengelolaan anggaran yang baik merupakan salah satu bagian penting dalam sistem manajemen pengelolaan keuangan daerah. Ciri utama dalam pengelolaan anggaran yang baik adalah adanya akuntabilitas dan transparansi. Menurut Mardiasmo (2009:6), "transparansi yaitu keterbukaan pemerintah dalam membuat kebijakan kebijakan keuangan daerah sehingga dapat diketahui dan diawasi oleh DPRD dan masyarakat".

Pengendalian akunansi merupakan pengendalian intern yang dipakai organisasi sebagai suatu sistem untuk menjaga dan mengendalikan data akuntansi organisasi seperti laporan keuangan. Dengan adanya pengendalian akuntansi,organisasi dapat memastikan bahwa tindakan yang dilakukan terkait dengan operasional organisasi telah berjalan sesuai dengan prosedur dan aturan yang mengatur.

\section{TINJAUAN PUSTAKA}

Kejelasan Sasaran Anggaran. Sasaran merupakan tolak ukur atau panduan pemerintah daerah dalam menyusun kebijakan dan program kerja. Anggaran yang telah disusun secara spesifik dan jelas yang biasanya tertuang dalam rencana Anggaran Pendapadan dan Belanja Daerah (RAPBD) memuat rencana kerja keuangan tahunan pemerintah daerah dan strategi pemerintah daerah untuk mencapai tujuan daerah. Anggaran yang telah dibuat dapat dikatakan baik apabila memuat informasi tentang pendapatan, belanja, pembiayaan, serta memberikan informasi mengenai kondisi kinerja pemerintah dalam konteks pengelolaan keuangan daerah termasuk didalamnya pengelolaan anggaran.

Transparansi. Salah satu karakteristik terciptanya good governance adalah adanya asas transparansi. Terkait dengan pelaksanaan pemerintahan transparansi menjadi suatu hal yang penting selain sebagai asas keterbukaan dalam memberi dan menerima informasi, transparansi juga menjadi suatu momok bagi oknum-oknum yang memiliki kepentingan pribadi atau ingin melakukan praktik korupsi.

Pengendalian Akuntansi. Sistem pengendalian akuntansi merupakan salah satu bagian dari sistem pengendalian intern yang berguna untuk mengelola dan mengendalikan catatan-catan atau laporan keuangan organisasi secara menyeluruh. Dengan adanya pengendalian akunansi, laporan keuangan yang dibuat dapat dinilai dan diukur kelayakannya, serta dengan adanya pengendalian akuntansi maka akan meminimalisir terjadinya kesalahan.

Kinerja Manajerial. Kinerja manajerial adalah kinerja para individu yang bertanggung jawab terhadap kegiatan manajerial pada suatu instansi atau organisasi. Menurut Mahoney (1963), kinerja manajerial dapat menjadi suatu cara untuk para individu dalam mengaplikasikan instrument penilaian diri sendiri, dimana para individu tersebut diminta untuk menilai kinerja mereka terkait dengan kegiatan manajerial yang mereka tangani masing-masing. 


\section{METODE PENELITIAN}

Jenis Penelitian. Penelitian ini dikategorikan sebagai penelitian kuantitatif dengan pengertian bahwa data yang diperoleh dapat berbentuk bilangan atau nilai atau dapat juga berupa data kualitatif yang diangkakan.

Tempat dan Waktu Penelitian. Penelitian dilakukan di 4 OPD yang ada di Provinsi Sulawesi Utara yaitu diantaranya Dinas Perindustrian dan Perdagangan Daerah Provinsi Sulawesi Utara. Waktu penelitian dilaksanakan pada bulan Mei-Agustus Tahun 2018.

Populasi dan Sampel. Populasi adalah bagian secara umum suatu objek atau subjek yang memiliki ciri tesendiri atau secara khusus diinginkan oleh peneliti untuk dipelajari (Sugiyono, 2013). Dari pengertian tersebut, populasi dalam penelitian ini adalah seluruh aparat pemerintah yang bekerja pada instansi pemerintah yang menjadi objek dalam penelitian ini. Sampel yaitu bagian dari total populasi yang memiliki ciri khusus untuk diteliti (Sugiyono, 2013). Sampel adalah bagian dari populasi yang dipercaya dapat mewakili karakteristik populasi secara keseluruhan. Berdasarkan penjelasan diatas, peneliti mengambil sampel dengan karakteristik khusus sebagai berikut: 1)Responden merupakan pegawai yang masih aktif bekerja dalam organisasi perangkat daerah di Provinsi Sulawesi Utara. 2)Responden menduduki jabatan struktural yaitu sebagai Kepala OPD, Sekertaris/Kepala Bagian, Kepala Sub Bagian, Kepala Bidang dan Kepala Seksi.

Metode Pengumpulan Data. Data penelitian dikumpulkan dengan menggunakan kuesioner sebagai instrumen pengumpulan data yang sebelumnya sudah dibagikan kepada objek penelitian yaitu aparat pemerintah dalam hal ini para pimpinan atau kepala-kepala yang adi di Organisasi Perangkat Daerah Provinsi Sulawesi Utara. Kuesioner yang dibagikan berisi butir-butir pernyataan yang berkaitan dengan variabel yang diteliti dalam penelitian ini.

\section{HASIL ANALISIS DAN PEMBAHASAN}

4.1. Hasil Analisis

Uji Asumsi Klasik

Uji Normalitas

Tabel 1. One-Sample Kolmogorov-Smirnov Test

\begin{tabular}{llr}
\hline & & Unstandardized Residual \\
\hline $\mathrm{N}$ & & 50 \\
Normal Parameters & \\
& Mean & 0.0000000 \\
Most Extreme Differences & Std. Deviation & Absolute \\
& Positive & 4.37441188 \\
& Negative & 0.104 \\
Test Statistic & & 0.104 \\
Asymp. Sig. (2-tailed) & -0.072 \\
\hline a. Test distribution is Normal. & 0.104 \\
b. Calculated from data. & $0.200^{\mathrm{c}, \mathrm{d}}$ \\
c. Lilliefors Significance Correction. & \\
d. This is a lower bound of the true significance. & \\
\end{tabular}


Berdasarkan pada hasil tabel diatas jika dilihat Asymp. Sig maka dapat diketahui data residualnya berdistribusi normal karena tingkat signifikansi lebih besar dari 0,05.

\section{Uji Multikolinearitas}

Tabel 2. Coefficients ${ }^{\mathrm{a}}$

\begin{tabular}{|c|c|c|c|c|c|c|c|c|}
\hline \multirow[b]{2}{*}{ Model } & & \multicolumn{2}{|c|}{$\begin{array}{l}\text { Unstandardized } \\
\text { Coefficients }\end{array}$} & \multirow{2}{*}{$\begin{array}{c}\begin{array}{c}\text { Standardized } \\
\text { Coefficients }\end{array} \\
\text { Beta } \\
\end{array}$} & \multirow[b]{2}{*}{ t } & \multirow[b]{2}{*}{ Sig. } & \multicolumn{2}{|c|}{$\begin{array}{c}\text { Collinearity } \\
\text { Statistics }\end{array}$} \\
\hline & & B & Std. Error & & & & Tolerance & VIF \\
\hline 1 (Constant) & & 10.563 & 7.576 & & 1.394 & 0.170 & & \\
\hline $\begin{array}{l}\text { Kejelasan } \\
\text { Anggaran }\end{array}$ & Sasaran & 0.926 & 0.269 & 0.487 & 3.438 & 0.001 & 0.646 & 1.548 \\
\hline Transparansi & & -0.326 & 0.557 & -0.099 & -0.586 & 0.561 & 0.453 & 2.206 \\
\hline $\begin{array}{l}\text { Pengendalian } \\
\text { Akuntansi }\end{array}$ & & 0.693 & 0.315 & 0.335 & 2.199 & 0.033 & 0.557 & 1.797 \\
\hline
\end{tabular}

Dasar pengambilan keputusan pada uji multikolinearitas yaitu apabila tolerance lebih dari 0,1 dan VIF kurang dari 10 maka tidak terjadi multikolinearitas dan jika dilihat dari tabel diatas maka penelitian ini tidak terjadi multikolenearitas.

\section{Uji Heteroskedastisitas}

Tabel 3. Coefficients ${ }^{\mathrm{a}}$

\begin{tabular}{|c|c|c|c|c|c|}
\hline \multirow[b]{2}{*}{ Model } & \multicolumn{2}{|c|}{ Unstandardized Coefficients } & Standardized Coefficients & \multirow[b]{2}{*}{$\mathbf{t}$} & \multirow[b]{2}{*}{ Sig. } \\
\hline & B & Std. Error & Beta & & \\
\hline 1 (Constant) & -1.324 & 4.790 & & -0.276 & 0.784 \\
\hline Kejelasan Sasaran Anggaran & 0.257 & 0.170 & 0.269 & 1.509 & 0.138 \\
\hline Transparansi & -0.332 & 0.352 & -0.200 & -0.942 & 0.351 \\
\hline Pengendalian Akuntansi & 0.103 & 0.199 & 0.099 & 0.515 & 0.609 \\
\hline
\end{tabular}

Sumber: Data olahan Tahun 2018

Dasar pengambilan keputusan apabila tingkat signifikansi antara variabel independen dengan absolut residual lebih dari 0,05 maka tidak terjadi masalah heteroskedastisitas, tetapi jika signifikansi kurang dari 0,05 maka terjadi masalah heteroskedastisitas. Jika dilihat dari hasil tabel diatas maka dalam penelitian ini model regresi yang digunakan tidak terjadi masalah heteroskedastisitas.

\section{Uji Regresi Linier Berganda}

Tabel 4. Hasil uji regresi berganda

\begin{tabular}{|c|c|c|c|c|c|}
\hline \multirow[b]{2}{*}{ Model } & \multicolumn{3}{|c|}{ Unstandardized Coefficients Standardized Coefficients } & \multirow[b]{2}{*}{$\mathbf{t}$} & \multirow[b]{2}{*}{ Sig. } \\
\hline & B & Std. Error & Beta & & \\
\hline 1 (Constant) & 10.563 & 7.576 & & 1.394 & .170 \\
\hline Kejelasan Sasaran Anggaran & 0.926 & 0.269 & 0.487 & 3.438 & 0.001 \\
\hline Transparansi & -0.326 & 0.557 & -0.099 & -0.586 & 0.561 \\
\hline Pengendalian Akuntansi & 0.693 & 0.315 & 0.335 & 2.199 & 0.033 \\
\hline
\end{tabular}

a. Dependent Variable: Kinerja Manajerial

Angka yang ditampilkan pada hasil tabel Coefficients dimasukkan kedalam rumus regresi linier berganda, yaitu sebagai berikut:

$Y=10,563+0,926 X_{1}-0,326 X_{2}+0,693 X_{3}$ 


\section{Koefisien determinasi $\left(\mathbf{R}^{2}\right)$}

Tabel 5. Model Summary ${ }^{\mathrm{b}}$

\begin{tabular}{ccrrr}
\hline Model & R & R Square & Adjusted R Square & \multicolumn{2}{c}{$\begin{array}{c}\text { Std. Error of the } \\
\text { Estimate }\end{array}$} \\
\hline 1 & $0.636^{\mathrm{a}}$ & 0.404 & 0.365 & 4.51480 \\
\hline
\end{tabular}

a. Predictors: (Constant), Pengendalian Akuntansi, Kejelasan Sasaran Anggaran, Transparansi

b. Dependent Variable: Kinerja Manajerial

Hasil perhitungan nilai koefisien determinasi $\left(\mathrm{R}^{2}\right)$ yang ditampilkan pada hasil output diatas adalah 0,404 artinya 40,4\% dari variasi Kinerja Manajerial Pemerintah Daerah Provinsi Sulawesi Utara yang dapat dijelaskan melalui variabel Kejelasan Sasaran Anggaran, Transparansi dan Pengendalian Akuntansi. Sedangkan sisanya yaitu sebesar 0,596 atau $59,6 \%$ dipengaruhi oleh faktor-faktor yang tidak diteliti dalam penelitian ini.

Uji t. Pengujian hipotesis pada uji t adalah untuk mengetahiui pengaruh setiap variabel dependen terhadap variabel independen secara masing-masing.

\begin{tabular}{|c|c|c|c|c|c|c|}
\hline \multicolumn{7}{|c|}{ Tabel 6. Coefficients ${ }^{a}$} \\
\hline & \multirow[b]{2}{*}{ Model } & \multicolumn{2}{|c|}{$\begin{array}{l}\text { Unstandardized } \\
\text { Coefficients }\end{array}$} & \multirow{2}{*}{$\begin{array}{c}\begin{array}{c}\text { Standardized } \\
\text { Coefficients }\end{array} \\
\text { Beta } \\
\end{array}$} & \multirow[b]{2}{*}{$\mathbf{T}$} & \multirow[b]{2}{*}{ Sig. } \\
\hline & & B & Std. Error & & & \\
\hline 1 & (Constant) & 10.563 & 7.576 & & 1.394 & 0.170 \\
\hline & Kejelasan Sasaran Anggaran & 0.926 & 0.269 & 0.487 & 3.438 & 0.001 \\
\hline & Transparansi & -0.326 & 0.557 & -0.099 & -0.586 & 0.561 \\
\hline & Pengendalian Akuntansi & 0.693 & 0.315 & 0.335 & 2.199 & 0.033 \\
\hline
\end{tabular}

Berdasarkan hasil output diatas dapat diketahui bahwa: Pertama, tingkat signifikansi dari variabel Kejelasan Sasaran Anggaran (X1) adalah 0,001 < 0,05 hal ini berarti $\mathrm{H}_{0}$ ditolak, $\mathrm{H}_{\mathrm{a}}$ diterima, dengan kata lain Kejelasan Sasaran Anggaran berpengaruh terhadap variabel Kinerja Manajerial pada Pemerintah Daerah Provinsi Sulawesi Utara (Y). Kedua, tingkat signifikansi dari variabel Transparansi (X2) 0,561 > 0,05 hal ini berarti $\mathrm{H}_{0}$ diterima, $\mathrm{H}_{\mathrm{a}}$ ditolak, dengan kata lain Transparansi tidak berpengaruh terhadap variabel Kinerja Manajerial pada Pemerintah Daerah Provinsi Sulawesi Utara (Y). Ketiga, tingkat signifikansi dari variabel Pengendalian Akuntansi (X3) $0,033<0,05$ hal ini berarti $\mathrm{H}_{0}$ ditolak, $\mathrm{H}_{\mathrm{a}}$ diterima, dengan kata lain Pengendalian Akuntansi berpengaruh secara signifikan terhadap variabel Kinerja Manajerial pada Pemerintah Daerah Provinsi Sulawesi Utara (Y).

\section{Uji F}

Tabel 7. ANOVA ${ }^{\mathrm{a}}$

\begin{tabular}{llrrrrr}
\hline & Model & Sum of Squares & df & Mean Square & F & Sig. \\
\hline 1 & Regression & 636.142 & 3 & 212.047 & 10.403 & $0.000^{\mathrm{b}}$ \\
& Residual & 937.638 & 46 & 20.383 & & \\
& Total & 1573.780 & 49 & & & \\
\hline
\end{tabular}

a. Dependent Variable: Kinerja Manajerial

b.Predictors: (Constant), Pengendalian Akuntansi, Kejelasan Sasaran Anggaran, Transparansi

Dari hasil output diatas dapat diketahui bahwa tingkat signifikansi dari variabel Kejelasan Sasaran Anggaran (X1), Transparansi (X2) dan Pengendalian Akuntansi (X3) adalah 0,000 < 0,05 hal ini berarti bahwa $\mathrm{H}_{0}$ ditolak dan $\mathrm{H}_{\mathrm{a}}$ diterima. Dengan kata lain secara simultan 
Kejelasan Sasaran Anggaran (X1), Transparansi (X2) dan Pengendalian Akuntnasi (X3) berpengaruh secara signifikan terhadap Kinerja Manajerial Pemerintah Daerah Provinsi Sulawesi Utara (Y).

\subsection{Pembahasan}

Pengaruh Kejelasan Sasaran Anggaran Terhadap Kinerja Manajerial Pada Pemerintah Provinsi Sulawesi Utara. Dari hasil output SPSS diketahui bahwa tingkat signifikansi dari variabel Kejelasan Sasaran Anggaran (X1) adalah 0,001 $<0,05$ hal ini berarti Kejelasan Sasaran Anggaran berpengaruh positif terhadap variabel Kinerja Manajerial pada Pemerintah Daerah Provinsi Sulawesi Utara. Hal ini berarti sasaran anggaran yang jelas akan mempermudah pemerintah daerah dalam menetukan target-target anggaran sehingga pemerintah daerah Provinsi Sulawesi Utara akan lebih mudah menyusun anggaran dan menghemat waktu dalam penyusunan anggaran. Locke \& Latham (1984) berpendapat bahwa sasaran anggaran yang jelas akan membuat pihak yang berkepentingan dalam penyusunan anggaran untuk semakin selektif dan berusaha semaksimal mungkin memberikan hasil yang baik agar tidak tidak terjadi kesalahan yang tidak diinginkan.

Pengaruh Transparansi Terhadap Kinerja Manajerial Pada Pemerintah Provinsi Sulawesi Utara. Dari hasil output SPSS dapat diketahui bahwa tingkat signifikansi dari variabel Transparansi (X2) 0,561 > 0,05 hal ini berarti Transparansi tidak berpengaruh terhadap variabel Kinerja Manajerial pada Pemerintah Daerah Provinsi Sulawesi Utara. Dari hasil tersebut peneliti mengindikasikan alasan transparansi tidak memiliki pengaruh terhadap kinerja manajerial pada Pemerintah Provinsi Sulawesi Utara karena Pada proses pengambilan keputusan terkait penyusunan anggaran di SKPD pihak yang terlibat adalah Kepala SKPD sebagai manajer tingkat atas dan Pejabat Penatausahaan Keuangan SKPD. Sedangkan para manajer tingkat bawah dalam hal ini kepala bagian, kepala bidang, kepala sub bagian dan kepala seksi, penelti berasumsi bahwa mereka hanya sebatas memberikan pengajuan anggaran untuk keperluan bidang masing-masing yang dibawahinya. Kristianten (2006) mengemukakan bahwa transparansi akan membantu dalam tata pemerintahan.

Pengaruh Pengendalian Akuntansi Terhadap Kinerja Manajerial Pada Pemerintah Provinsi Sulawesi Utara. Dari hasil output SPSS dapat diketahui bahwa tingkat signifikansi dari variabel Pengendalian Akuntansi (X3) 0,033 $<0,05$ hal ini berarti Pengendalian Akuntansi berpengaruh positif terhadap variabel Kinerja Manajerial pada Pemerintah Daerah Provinsi Sulawesi Utara. Dengan adanya pengendalian akuntansi, para manajerial sudah melaksanakan tugas dan fungsinya dalam penyusunan anggaran sesuai dengan prosedur yang berlaku selain itu manajerial juga turut mengontrol dan mengawasi kegiatan yang ada di instansi tersebut. Menurut Anthony (2000) pengendalian akuntansi sejatinya merupakan suatu alat pengendalian yang memiliki fungsi untuk mengatur dan mengendalikan organisasi dalam pelaksanaan kegiatan atau operasionalnya dalam hal pencatatan laporan keuangan sehingga pada saat terjadi pemeriksaan atau audit baik audit intern maupun eksternal laporan yang dihasilkan mendapat opini yang wajar seperti yang diharapkan.

Pengaruh Kejelasan Sasaran Anggaran, Transparansi dan Pengendalian Akuntansi Terhadap Kinerja Manajerial Pada Pemerintah Provinsi Sulawesi Utara. Pengujian hipotesis pada uji $\mathrm{F}$ bertujuan untuk mengetahui pengaruh seluruh variabel dependen terhadap variabel independen secara simultan. Diketahui bahwa tingkat signifikansi dari variabel Kejelasan Sasaran Anggaran (X1), Transparansi (X2), dan Pengendalian Akuntansi (X3) adalah adalah 0,000 <0,05 hal ini berarti bahwa $\mathrm{H}_{0}$ ditolak dan $\mathrm{H}_{\mathrm{a}}$ diterima. Dengan kata lain secara simultan Kejelasan Sasaran Anggaran (X1), Transparansi (X2) dan Pengendalian Akuntnasi (X3) berpengaruh secara signifikan terhadap Kinerja Manajerial Pemerintah Daerah Provinsi Sulawesi Utara (Y). 


\section{KESIMPULAN DAN SARAN}

\subsection{Kesimpulan}

Kesimpulan yang dapat diambil dari hasil penelitian dan pembahasan yang telah bahas sebelumnya, adalah sebagai berikut:

1. Kejelasan Sasaran Anggaran berpengaruh terhadap Kinerja Manajerial pada Pemerintah Provinsi Sulawesi Utara.

2. Transparansi tidak berpengaruh terhadap Kinerja Manajerial pada Pemerintah Provinsi Sulawesi Utara.

3. Pengendalian Akuntansi berpengaruh terhadap Kinerja Manajerial pada Pemerintah Provinsi Sulawesi Utara.

4. Kejelasan Sasaran Anggaran, Transparansi dan Pengendalian Akuntansi secara simultam berpengaruh terhadap Kinerja Manajerial pada Pemerintah Provinsi Sulawesi Utara.

\subsection{Saran}

Saran untuk Pemerintah Provinsi Sulawesi Utara, sekiranya dalam penyusunan anggaran hendaknya dilaksanakan dengan sebaik-baiknya dengan prinsip keterbukaan/transparan dan sesuai dengan prosedur yang berlaku,untuk menyusun serta melaksanakannya. Selain itu perlu diberikan pemahan sasaran anggaran yang jelas kepada setiap oknum yang terlibat dalam proses penganggaran sehingga dalam penyusunan anggaran sudah dapat memperkirakan program, prioritas, waktu dan biaya yang akan digunakan sehingga dapat meningkatkan efektivitas dan efisiensi kinerja aparat pemerintah atau kinerja manajerial demi tercapainya visi dan misi daerah.

\section{DAFTAR PUSTAKA}

Anthony, Robert, N. dan Vijay, Govindarajan. 2000. Sistem Pengendalian Manajemen. Buku 2. Jakarta: Salemba Empat

Bastian, Indra, 2010. Akuntansi Sektor Publik: Suatu Pengantar. Penerbit Erlangga, Jakarta Didjaja, Mostofa. 2003. Transparansi Pemerintah. Jakarta: Rineka Cipta.

Efrizar, Rona. 2017. Pengaruh Kejelasan Sasaran Anggaran, Akuntabilitas Publik, Dan Sistem Pelaporan Terhadap Kinerja Manajerial. Faculty of Economics Riau University, Pekanbaru, Indonesia. JOM Fekon, Vol. 4 No. 1. Hal:1726-1740.

Halim dan Kusufi, 2012. Akuntansi Sektor Publik: teori, konsep dan aplikasi. Salemba Empat:Jakarta.

Hery, 2013. Teori Akuntansi. Lembaga Penerbit. FE-UI. Jakarta

Kristianten, 2006. Transparansi Anggaran Pemerintah. Jakarta: Rineka Cipta.

Mardiasmo, 2009. Akuntansi Sektor Publik Penerbit ANDI, Yogyakarta

Mohammad, Mahsun. 2013. Pengukuran Kinerja Sektor Publik. Yogyakarta: BPFE.

Priyanto Duwi, 2016. Belajar Analisis Data dan Cara Pengolahannya Dengan SPSS. Gava Media. Yogyakarta

Sugiyono. 2010. Metode Penelitian Kuantitatif Kualitatif dan R\&D. Bandung:Alfabeta.

Suhartono, Erhmann dan Mochammad Solichin. Pengaruh Kejelasan Sasaran Anggaran terhadap senjangan Anggaran Instansi Pemerintah Daerah dengan Komitmen Organisasi sebagai Pemoderasi. Simposium Nasional Akuntansi Vol. 9. 2006.Hal 120. 